\title{
REVIEW \\ Recent Progress of Strawberry Year-round Production Technology in Japan
}

\author{
Atsushi YAMASAKI* \\ Field Crop and Horticulture Division, NARO Tohoku Agriculture Research Center, National Agricul- \\ ture and Food Research Organization (NARO) (Morioka, Iwate 020-0123, Japan)
}

\begin{abstract}
In Japan, more than $90 \%$ of strawberries are produced by forcing culture, which involves inducing flowering in autumn by several artificial methods (e.g. chilling, short-day), growing plants under a heated greenhouse to avoid the induction of dormancy and dwarfing, and keeping them in a semi-dormant state to allow continued harvesting. Although the normal harvest period is from late November to June, progress in technological research and the development of forcing has contributed to such long-term harvests. In forcing culture, it is important to understand the dormancy status of the strawberry plants, since controlling dormancy is key to realizing long-term successive harvests between winter and early summer. However, the last two decades have seen increasing demand for a year-round supply of strawberries for confectioners. Recent progress in the research and development of strawberry year-round production technology is reviewed with special reference to the activities of a summer-autumn production research team in the Tohoku region.
\end{abstract}

Discipline: Horticulture

Additional key words: dormancy, everbearing, flower initiation, forcing culture, high temperature

\section{Introduction}

Wild species from North and South America are the origin of the cultivated strawberry, a winter-dormant plant for which relatively cool climates are standard. Low temperatures or short-day photoperiods in autumn induce flower bud initiation and the start of dormancy, which is later broken by sufficient chilling. The subsequent high temperatures and long-day photoperiods in spring promote vegetative growth, leaf elongation, runner development, and blooming. Based on this life cycle, strawberries are usually harvested from May to June in open fields. Over several decades, the production season has been extended to mid-November, and continuing into May. These changes represent remarkable progress in terms of developing a successive production system, strawberry forcing cultivation technology, and breeding new varieties. This progress is the result of research conducted at Japanese research institutes and universities ${ }^{13,24}$. However, as a result, the supply of strawberries has been focused on winter and spring seasons in Japan. From July to October, when strawberries are scarce, imported fruit from California meet demand. However, the increasing demand for summer-autumn strawberries from confectioners has spurred research into summer-autumn production.

The following is a review of the research achievements describing the current state of year-round strawberry production technology, with special reference to the results of the research project around the Tohoku region.

\section{Establishment of forcing culture}

In Japan, more than 90 percent of strawberries are produced by forcing and semi-forcing culture. The forcing culture originated with a "Ishigaki ichigo" in Shizuoka, whereupon many technical problems related to breeding, growth, and development were subsequently solved. The "Hoko wase" cultivar was used to pioneer long-term forcing cultivation with supplemental lighting and gibberellin application; led by Fujimoto (1972) in Nara Prefecture ${ }^{2}$. Fujimoto's research enabled long-term, out-of-season production from December to June. The stable supply of virus-free plants from the regional foundation stock farms

* Corresponding author: e-mail yamasaki@affrc.go.jp

Received 13 October, 2011; accepted 25 April, 2012. 
also contributed significantly to the establishment of forcing culture ${ }^{21}$.

Conversely, the temperature differences and harsher winters in northern locales, such as Hokkaido and Tohoku, meant other cultivation systems were necessary, one of which, developed by Takai and Seyama (1978), is a dormancy-extended semi-forcing culture ${ }^{22}$. Here, chilling is controlled so that the dormancy is not completely broken and successive flowering and vegetative vigor continues from April to July.

In both systems, the importance of controlling the dormant status for successive flowering and shoot growth should be emphasized. The dormancy of strawberry plants is induced by a short-day photoperiod and low temperature and released by sufficient chilling. In spring, dormancybroken plants produce a long petiole and large leaf blades and runner stolons, and cease to initiate flower bud, even if exposed to a suitable temperature and photoperiod for flower budding for several months (Fig. 1). Therefore, in the Japanese forcing culture, the winter temperature needs to be regulated so that the plants are not exposed to dormancy-inducing low temperature, normally below $5^{\circ} \mathrm{C}^{14}$. Furthermore, the plants need to be kept in a non-dormant or semi-dormant state, because sufficiently chilled plants break their dormancy and cease to initiate flower bud $\mathrm{d}^{20,35}$.

Subsequently the interest of growers and researchers turned toward progress in harvesting time, as the varieties used for forcing culture were those with fewer chilling requirements. In earlier research, nitrogen was assumed to be heavily involved in the flower bud initiation process ${ }^{2}$. Consequently, waiting beds in nursery plant production, which required root pruning, rapidly gave way to the use of polyethylene pots or plugging. Nursery plant production by pots and plugs was effective, not only for early harvesting in November but also for protecting plants from anthracnose and Fusarium wilt, but required more labor. In the 1980s, new techniques for flower bud induction, such as short-day/low-temperature treatment and dark/low-temperature treatment $\left(10-15^{\circ} \mathrm{C}\right)$, mainly for 'Nyoho' and 'Toyonoka', respectively, were established

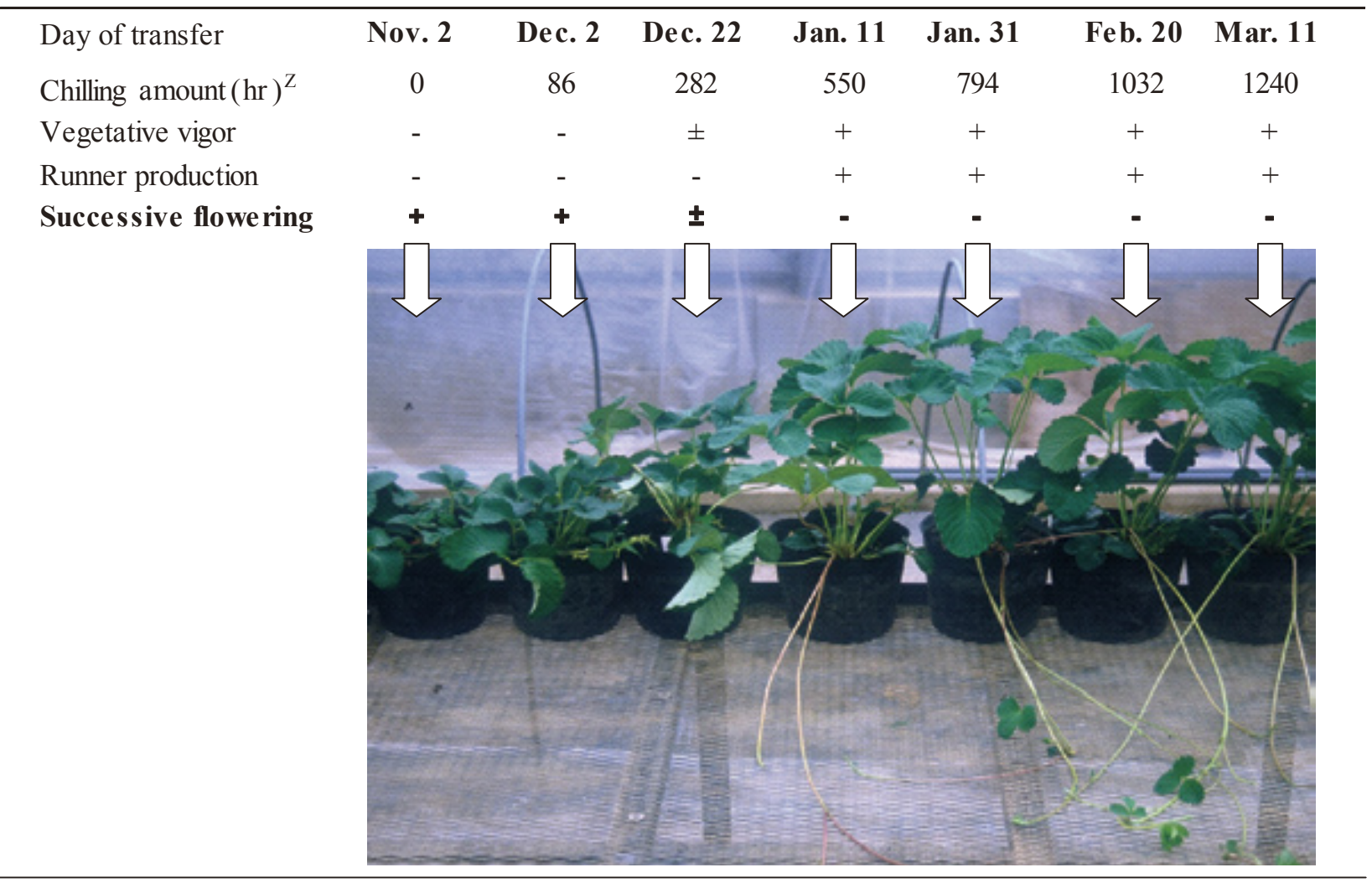

Fig. 1. Effect of chilling on vegetative vigor, runner production and flowering

${ }^{z}$ Number of hours exposed to temperature below $5{ }^{\circ} \mathrm{C}$

'Sachinoka' plants were transferred to a warm greenhouse (min. $18{ }^{\circ} \mathrm{C} / 12 \mathrm{hr}$ photoperiod) from outside at 20- or 30-day intervals. The inflorescences were removed after the blooming of the first flower. 
and widely adopted in areas with forcing culture. Simultaneously, limiting the nitrogen supply for flower bud induction also became an essential cultural technique ${ }^{6,25,29}$ and enabled such induction at any time. However, actual year-round production was not practiced because the excessive progress of flower initiation inhibited successive flowering, and fruit quality could not be maintained in the high summer and autumn temperatures. In summary, the main factors affecting year-round production are the maintenance of successive flowering and fruit quality at high temperatures.

\section{Current research into summer-autumn production}

As reported above, the harvest season for forcing culture is currently November to June. From July to October, when strawberries are scarce, imported fruit from California meets demand. However, confectioners have increased their demand for summer-autumn strawberries, which has spurred research into summer-autumn production.

Until the 1980s, many researchers sought a solution to the difficult problem of fruit production in summer and autumn with June-bearing varieties, due to the lack of high-quality ever-bearing varieties at that time.

\section{Use of June-bearing varieties}

Summer-autumn production using cold-stored plants was temporarily widespread in Japan in the 1960s and 1970s. Since cold-stored plants are placed in chilled storage at $-1{ }^{\circ} \mathrm{C}$, they do not initiate new flower buds and consequently have a low yield. Subsequently, however, this production gradually disappeared in favor of forcing culture as the mainstream and increased imports from the United States.

However, cold-stored plants are used globally, with successive cropping of 'Elsanta' performed in the Netherlands and Belgium and spring transplanting in California. Cold-stored plants have also recently been tested for successive cropping or varietal performance in Japan ${ }^{34,36}$.

Furthermore, summer-autumn production achieved with short days was also investigated in the colder parts of Japan in the 1960s. Recently, project-team research conducted in the Tohoku region produced interesting results from summer-autumn production, based on which small growing districts are now developing ${ }^{31}$. A new method of short-day treatment for daughter plant production using runner-connected mother plants was also developed $^{28}$. However, in cold areas, summer-autumn production achieved with short-day treatments presents its own problems, such as the interruption of successive flowering. When growers want to continue forcing culture by maintaining appropriate temperatures with the same plants used for summer-autumn culture in winter, they will have several months of blank harvest. Excessive progress of flower bud initiation usually inhibits the axillary flower bud initiation in this cropping system because the thermal and photoperiodical conditions at the time of transplanting in summer are unsuitable for flower bud initiation. It is therefore preferable to cease applying the maintaining temperature in cold areas following the harvest of forced primary inflorescence, whereupon plants are forced to be dormant for a while. Subsequently, in early spring, plants start to regrow and bloom. With this method, plants are overexposed to low temperatures to break their dormancy and thus temporarily stop responding to any flower bud induction stimulus. In other words, successive flowering temporarily stops. This phenomenon is also known as a "post-chilling physiological condition" and is considered to impair forcing culture in cold northern areas. Recently, a study quantifying the period for which strawberry plants do not respond to flowering stimulus after sufficient chilling was conducted ${ }^{35}$. Although maintaining temperatures in winter is economically possible in cold districts, it is very difficult to maintain successive flowering after the chilling requirement is satisfied and further studies on dormancy and the flowering process are required. In future, it would be beneficial to develop an improved forcing culture for cold areas where the cost of maintaining warmer temperatures is expensive.

In areas with a Mediterranean climate, such as California, the flowering habits of some June-bearing varieties sometimes change to everbearing varieties ${ }^{33}$, which is known as the "California effect". In Japan, the seasons are more pronounced than in California. However, if the exposure to chilling were reduced and dormancy maintained over winter, it would be possible to create an artificial "California effect" on the Pacific seaboard of northern Tohoku and Hokkaido ${ }^{12}$. The recently released early-flowering varieties, such as 'Saga-honoka,' will help make this possible. In the near future, new techniques for forcing culture that are more suited to cold districts should be developed.

\section{Use of everbearing varieties}

In recent decades, everbearing varieties have been actively and intensively bred and released by government institutes and private companies ${ }^{23}$, although limited information exists on the growth and flowering habits of everbearers. Everbearing varieties, including day-neutral ones, are considered insensitive to photoperiod in flower bud initiation, but some were recently determined as longday plants under a high-temperature regime $e^{15,16}$. For example, most everbearers develop fewer runner plants than Junebearers. In addition, everbearers sometimes develop 
excessive branch crowns, inflorescences, and flowers, meaning more management and labor is required for debudding, pruning, and thinning. Some recent noteworthy work includes studies on the photoperiodic response of flowering under high temperature regimes ${ }^{15,16,18}$, flower induction by long-day treatment ${ }^{9}$, the high temperature effects on flowering and fertilization ${ }^{3,4}$, the involvement of chilling and runner production ${ }^{7,8}$, seasonal changes in fruit sugar content ${ }^{5}$, the analysis of root structure ${ }^{30}$, and the application to forcing culture ${ }^{10}$. Despite the shortage of information on flowering physiology, there are many active breeding programs involving new everbearing varieties in public and private institutions.

It is also very difficult for both everbearers and Junebearers alike to overcome the effects of high summer temperatures, which affect the stability of flowering, fruit quality, and shelf life. However, the production area has spread to over 80 ha in Japan and is still increasing.

\section{Improvement of cultural conditions, especially high-temperature summer regimes}

As reported above, it is crucial to improve cultural conditions, especially high-temperature summer regimes, not only in Junebearers but also in everbearers. Several studies have been performed on the high-temperature effects on fruit development and fruit quality ${ }^{19}$, and it is obvious that high temperatures inhibit fruit growth and development and impair quality. Many technological approaches for coping with high temperatures within a greenhouse or high tunnels have been developed, several of which were presented at the 2007 spring JSHS sym$\operatorname{posium}^{27}$. For strawberries, there have been many trials to improve the temperature conditions around strawberry plants in summer, including localized cooling along the crown by cold water flowing in an aluminum tube ${ }^{1}$, root zone aeration ${ }^{11}$, and substrate cooling by vaporization from a porous sheet ${ }^{17,32}$.

Since nursery plants are not suited to high summer temperatures, plants were taken to higher elevations to induce flower buds in forcing culture until the 1980s. Recently, the long-distance movement of nursery plants has been implemented between Hokkaido and areas used for forcing culture instead of higher elevations. Saving labor is also a key issue in Japanese strawberry culture. In Japan, the number of working hours spent on nursery plant production is generally 15 to $20 \%$ of the total working hours expended on forcing culture fruit production. Progress in the specialization of nurseries by such long-distance nurseries could reduce the labor of many Japanese strawberry farmers in nursery production and promote large-scale fruit production.
To promote the specialization of nursery plant production, other special values should be added to the nursery plant, e.g. low price and the presence of flower buds. Currently, a unique nursery system is being developed, in which short-day treatment in summer-autumn production is simultaneously applied to daughter plants connected to mother plants by runners at a nursery site. The development of the labor- and cost-saving mass production of nursery plants with flower buds is anticipated ${ }^{28}$.

\section{References}

1. Dan, K. et al. (2007) Effect of temperature treatment of crown part on flowering of inflorescence in strawberry of forcing culture. Engeigaku kenkyu (Hort. Res. (Japan)), 6 (Suppl. 1), 428 [In Japanese].

2. Fujimoto, K. (1972) Studies on physiological and ecological characteristics of strawberry 'Hoko wase' and development of new cropping type. Nara nougyo shikenjo tokubetsu hokoku (Special Bull. Nara Agr. Exp. Stn.), 1, 1-151 [In Japanese with English summary].

3. Fukada, N. \& Kurogi, T. (2004) Effect of the high temperature on the growth, the floral differentiation and the fertility of everbearing strawberry. Engei gakkai zasshi (Jour. Japan. Soc. Hort. Sci.), 73 (Suppl. 1), 290 [In Japanese].

4. Fukada, N. et al. (2005) Effect of the short-time high temperature on the growth, floral differentiation and fertility of everbearing strawberry. Engei gakkai zasshi (Jour. Japan. Soc. Hort. Sci.), 74 (Suppl. 1), 305 [In Japanese].

5. Funatsu, M. et al. (2004) Seasonal changes in sugar contents of everbearing strawberry fruit in Hokkaido. Engei gakkai zasshi (Jour. Japan. Soc. Hort. Sci.), 73 (Suppl. 1), 292 [In Japanese].

6. Furuya, S. et al. (1988) Effects of nitrogen content on the flower bud initiation induced by chilling under dark condition in strawberries. Yasai shikenjo hokoku D (Bull. Veg. Ornam. Crops Res. Stn. Ser. D), 1, 51-57 [In Japanese with English summary].

7. Hamano, M. et al. (2009) Effect of chilling and day length on runner of everbearing type strawberry. Acta Horticulturae, 842, 671-674.

8. Hamano, M. et al. (2011) Effect of previous chilling, day length and cold storage on runnering habit in everbearing strawberry cultivars 'Natsuakari and 'Dekoruju'. Engeigaku kenkyu (Hort. Res. (Japan)), 10, 173-181 [In Japanese with English summary].

9. Hamano, M. et al. (2012) Effect of long-day treatments before planting on flower initiation and autumn yield of first-year runner plant of everbearing strawberry 'Natsuakari'. Engeigaku kenkyu (Hort. Res. (Japan)), 
11, in press [In Japanese with English summary].

10. Imada, S. et al. (2005) Yield and flower bud appearance time in annual plants of everbearing type strawberry 'Natsuakari' under forcing culture. Engei gakkai zasshi (Jour. Japan. Soc. Hort. Sci.), 75 (Suppl. 2), 273 [In Japanese].

11. Iwasaki, Y. (2008) Root zone aeration improves growth and yields of coir-cultured strawberry (Fragaria ananassa Duch.) during summer. Acta Horticulturae, 779, 251-254.

12. Iwase, T. (2005) Year-round production of strawberry in Yamase climate district. Noko to Engei (Agriculture and Horticulture), 60, 186-189 [In Japanese].

13. Mochizuki, T. et al. (2007) Recent trends on strawberry cultivars and production technology in Japan. Acta Horticulturae, 761, 107-113.

14. Mochizuki, T. et al. (2009) Forcing culture of strawberry in Japan - production technology and cultivars. Acta Horticulturae, 842, 107-109.

15. Nishiyama, M. \& Kanahama, K. (2002) Effects of temperature and photoperiod on flower bud initiation of day-neutral and everbearing strawberries. Acta Horticulturae, 567, 253-255.

16. Nishiyama, M. et al. (2007) Varietal differences in critical photoperiod for inflorescence production among day-neutral strawberry cultivars. Acta Horticulturae, 761, 207-213.

17. Oki, A. et al. (2005) Effect of cooling system of strawberry for summer and autumn production on the bench cultivation. Engei gakkai zasshi (Jour. Japan. Soc. Hort. Sci.), 74 (Suppl. 2), 439 [In Japanese].

18. Okimura, M. et al. (2004) Effects of photoperiod on flowering and runnering of everbearing strawberry cultivars in warmer regions. Engei gakkai zasshi (Jour. Japan. Soc. Hort. Sci.), 73 (Suppl. 2), 173 [In Japanese].

19. Pipattanawong, R. et al. (2009) Effect of high temperature on pollen-pistil fertility and development of embryo and achene in 'Tochiotome' strawberry. J. Japan. Soc. Hort. Sci., 78, 300-306.

20. Seyama, N. \& Takai, T. (1986) Study on the seasonal pattern of the growth and flower formation of strawberry plants as related to environment and endogenous physiological conditions. Yasai sikenjo hokoku B (Bull. Veg. Ornam. Crops Res. Stn. Ser. B), 6, 31-77 [In Japanese with English summary].

21. Shoji, K. (1990) Strawberry production using virusfree plants. Baio Horuthi (BioHorti), 1, 94-96 [In Japanese].

22. Takai, R. \& Seyama, N. (1978) Establishment of a new culturing system for strawberry in the northern part of Japan. I. On autumn covering with plastic in the semi-forced strawberry culture. Yasai shikenjo hokoku B (Bull. Veg. Ornam. Crops Res. Stn. Ser. B), 2, 43-53 [In Japanese with English summary].

23. Takahashi, H. (2006) Present status and prospects of everbearing strawberry breeding in northern Japan. Engeigaku kenkyu (Hort. Res. (Japan)), 5, 213-217 [In Japanese with English summary].

24. Takahashi, H. et al. (2009) Present status and prospects of strawberry breeding and cropping type in northern Japan. Acta Horticulturae, 842, 475-478.

25. Yamasaki, A. et al. (2002) Tracer studies on the allocation of carbon and nitrogen during flower induction of strawberry plants as affected by the nitrogen level. Acta Horticulturae, 567, 349-352.

26. Yamasaki, A. et al. (2005) Effect of nursery period and attached mother plant on flowering of strawberry by short-day treatment. Engei gakkai zasshi (Jour. Japan. Soc. Hort. Sci.), 74 (Suppl. 1), 303 [In Japanese].

27. Yamasaki, A. (2007) Current progress of strawberry year-round production technology in Japan. Proceedings Intl. Symposium on Strawberry Production and Research in East Asia. Kyoto, Japan, 1-8.

28. Yamasaki, A. et al. (2007) Improving the efficiency of short-day propagation by retaining the stolon connection of the runner plant. Proceedings 2007 North American Strawberry Symposium, Ventura, California, 38-41.

29. Yamasaki, A. \& Yano, T. (2009) Effect of supplemental application of fertilizers on flower bud initiation and development of strawberry - possible role of nitrogen. Acta Horticulturae, 842, 765-768.

30. Yamashita, M. \& Okimura, M. (2006) Influences of high root confinement on growth and root system structure of everbearing strawberry 'Eran'. Engei gakkai zasshi (Jour. Japan. Soc. Hort. Sci.), 75 (Suppl. 2), 271 [In Japanese].

31. Yamazaki, H. et al. (2006) Mapping of meteorologically-suitable area for autumn-harvesting strawberries in Tohoku region. Tohoku nogyo kenkyu (Tohoku Agric. Res.), 59, 179-180 [In Japanese].

32. Yamazaki, K. et al. (2009) Shortening of non-harvest period in high-bench strawberry forcing culture by a simple control method of medium temperature. Acta Horticulturae, 842, 733-736.

33. Yanagi, T. (1992) Studies on the everbearing behavior of cultivated strawberry (Fragaria $\times$ ananassa Duch.) with special reference to effects of day length and temperature. Osaka furitsudaigaku kiyou B (Bull. Univ. Osaka Pref. Ser. B), 44, 115-144 [In Japanese with English summary].

34. Yano, T. et al. (2006) Effect of planting dates with cold-stored plants of strawberry cultivars for forcing 
on flowering and yield. Engei gakkai zasshi (Jour. Japan. Soc. Hort. Sci.), 75 (Suppl. 1), 113 [In Japanese].

35. Yano, T. et al. (2006) Out-of-season production of strawberry in summer using overwintered plants: Effects of cumulative temperature after release from dormancy on flower initiation. Abstr. 27th Intl. Hort. Congr., 206.

36. Yoshida, Y. \& Morimoto, Y. (2003) Summer-production of June-bearing strawberry with cold-stored plants. Engei gakkai zasshi (Jour. Japan. Soc. Hort. Sci.), 72 (Suppl. 2), 163 [In Japanese]. 